\title{
Sandviç Kompozit Tabakalarında Mekanik Gerilmelerin Basınca Bağlı Olarak Ansys Yazılımı İle İncelenmesi
}

\author{
Investigation Of Mechanical Stresses On Sandwich Composite Layers According To The \\ Pressure By Making Use Of Ansys Software
}

\author{
Kürşat KAYMAZ ${ }^{1, a}$, Bilgin ZENGİN²,b, Muzaffer AȘKIN ${ }^{2, c}$, Semih TAȘKAYA ${ }^{3, \mathrm{~d}}$ \\ ${ }^{1}$ İnşaat Mühendisliği Bölümü, Mühendislik Fakültesi, Üniversitesi Munzur, Tunceli \\ ${ }^{2}$ Elektrik ve Elektronik Mühendisliği Bölümü, Mühendislik Fakültesi, Üniversitesi Munzur, Tunceli \\ ${ }^{3}$ Metalurji ve Malzeme Mühendisliği Bölümü, Teknoloji Fakültesi, Üniversitesi Fırat, Elazı̆̆
}

• Geliş tarihi / Received: 30.05 .2018 •Düzeltilerek geliş tarihi / Received in revised form: 15.10.2018 • Kabul tarihi / Accepted: 06.11.2018

$\ddot{O} z$

Bu çalışmada; Ansys paket programında, 3 ara tabakadan oluşan, düz ve $7^{0}$ lik oryantasyon açısına sahip radyal geometrili 2 farklı model, x, y, z koordinat ölçülerine göre 3 boyutlu olarak tasarlanmıştır. Düz ve radyal geometriye sahip sandviç tabakaların 2 farklı testte, sağ ve sol mesnetlerden ankastre ve çizgisel olarak sabitlenerek 4 MPa basınç altında eksenlere göre mekanik gerilim analizleri yapılmıştır. Geometrik şekilleri aynı-mesnetleri farklı ve geometrik şekilleri farklı-mesnetleri aynı yapılar karşılaştırılarak incelenmiştir. Geometrik şekilleri aynı-mesnetleri farklı gerilim sonuçlarında, düz ankastreli mesnetin çekme oranlarının çizgisel mesnete göre artış gösterdiği ve sıkıştırma oranlarının ise azalış gösterdiği görülmüştür. Radyal ankastreli mesnetin çekme oranlarının çizgisel mesnete göre azalış gösterdiği ve sıkıştırma oranlarının ise $\mathrm{x}$ ekseninde arttığı, y ve z eksenlerinde azaldığı görülmüsşür. Geometrik şekilleri farklımesnetleri aynı gerilim sonuçlarında ise, radyal ankastreli mesnetin düz mesnete göre hem çekme ve hem de sıkıştırma oranlarının y ekseninde arttı̆̆ı, x ve z ekseninde azaldığı görülmüştür. Radyal çizgisel mesnetin düz mesnete göre, $x$ ekseninde çekme ve sıkıştırma oranlarının azaldığ 1 y ekseninde arttığı, z ekseninde ise çekme oranının arttığı sıkıştırma oranının azaldığı görülmüştür.

Keywords: Ansys, Düz ve Radyal Tabaka, Mekanik Gerilim, Sandviç Kompozit.

\begin{abstract}
In this study, in Ansys package program 2 different models of 3 intermediate layers, with a straight and $7^{\circ}$ orientation angle, are designed as 3 dimensional according to $x, y, z$ coordinate measurements. Sandwich plates with smooth and radial geometries were fixed in two different tests from their right and left supports, linearly and mechanical stresses were analyzed according to axes under $4 \mathrm{MPa}$ pressure. Here, we mainly analysed two different structures by comparing features according to the cases that having same shape-different supports and different shapes-same support. It has been investigated that the compression ratios of straight anchorage support increase linearly as a function of linear meshes in the same geometry but different support stresses. The radial anchorage support draw ratio decreases with linear supports while the compression ratios increase with $x$ axis and decrease with $y$ and $z$ axes. On the other hand, it is concluded that radial anchorage ratio for the structures having different shapes and same type supports increases in $x$ axis and decreases in both $y$ and $z$. Moreover, one can see that radial linear support has lower draw and compression ratios on the $x$ axis, and also the quantity increases on the $y$ axis while the compression ratio decreases on the z axis.
\end{abstract}

Anahtar kelimeler: Ansys, Flat and Radial Layer, Mechanical Tension, Sandwich Composite.

\footnotetext{
${ }^{* b}$ Bilgin ZENGIN; bilginzengin@munzur.edu.tr ; Tel 0 (428) 213 17 94; orcid.org/0000-0002-9355-8294

${ }^{a}$ orcid.org/0000-0002-8346-8260 $\quad{ }^{c}$ orcid.org/0000-0001-9172-6592 $\quad{ }^{\mathrm{d}}$ orcid.org/0000-0003-1524-4537
} 


\section{Giriş}

Son yıllarda azaltılmış ağırlık ve daha iyi mekanik performans ile karakterize edilen yapıları keşfetmeye yönelik artan çabalar, esas olarak kara ve deniz taşımacılığında sandviç yapıların geliştirilmesine ve istihdam edilmesine yol açmıştır (Atckinson, 1997). Yapısal bir sandviç, tek bir özelliği ile küresel yap1 performansında işbirliği yapmak için bir araya getirilmiş farklı malzemelerin bir kombinasyonu ile karakterize edilen özel bir katmanlı kompozit tipidir. $\mathrm{Bu}$ yapıların tasarlanmasında ve doğrulanmasında asıl sorun, doğru modellemelerine izin vermeyen kendi içsel anizotropi ve homojen olmayan olmalarıdır. Günümüzde, doğru ve güvenilir bir tasarıma izin vermek için gerekli olan karmaşık yapıların mekanik özellikleri hakkındaki mevcut veriler yeterli değildir (Manning vd., 1993; Bannister vd., 1999). Sandviç yapıları, ağırlıkla ilişkili olarak önemli ölçüde sertlik ve yüksek mukavemet oranı gösteren hafif malzemelerdir. Sandviç panelin ana konsepti, diş yüzeylerin, bükülme (bükülme yükü ve sıkıştırma) nedeniyle oluşan yükleri transfer etmesidir. Buna göre, makroskopik olarak tarif edilen sandviç panelin çalışma modu, I-kiriş tarafindan gerçekleştirilen görevlerle doğru bir şekilde karşılaştırılabilir (Muc vd., 2005; Ochelski vd., 2007; Campbell, 2010). Ganapathi vd. (2004) bu öğeyi, termal / mekanik yüklere maruz kalın lamine kompozit ve sandviç plakaların doğrusal olmayan dinamik analizini gerçekleştirmek için kullanmışlardır. Tawfik vd. (2002), aerodinamik ve termal yüklere maruz kalan gömülü şekil hafizalı alaşım ile izotropik panelin termal post-burkulması ve aeroelastik davranışlarını incelemek için von Karman gerilme-yer değiştirme ilişkilerine dayanan doğrusal olmayan sonlu elemanlar modelini kullanmışlardır. Natarajan vd. (2014), nem konsantrasyonu ve termal gradyanın, lamine kompozit plakaların serbest titreşim ve burkulma özelliklerine etkisini incelemek için birinci mertebe kesme deformasyon teorisine dayanan uzatılmış sonlu elemanlar yöntemini kullanmışlardır. Park vd. (2004), termal yüklere maruz kalan şekil hafizalı alaşım lifleri ile gömülmüş lamine kompozit plakalar için lineer olmayan sonlu eleman denklemlerini formüle etmek için birinci sıra kesme deformasyon teorisini kullanmış ve önceden bükülmüş ve posttoklaştırılmış bölgelerdeki plakaların titreşim karakteristiklerini araştırmışlardır. Vangipuram ve Ganesan (2007), termal yükler altında sicaklığa bağlı viskoelastik çekirdek ile dikdörtgen kompozit viskoelastik sandviç plakaların serbest titreşim ve sönümleme özelliklerini incelemek için sonlu elemanlar yöntemini kullanmışlardır. Froud (1980), sandviç panellerin, avantajların ve göze çarpan özelliklerin temelini açıklamıştır. Ağırlık ve maliyet açısından optimum esneklik özelliklerini elde etmiştir. Ağırlık ve maliyet tasarrufu elde etmek için geometriyi seçerken tasarımcılar tarafından alınan güç, sertlik ve önlemlerin tasarım optimizasyonunun gerekliliğini vurgulamıştır. Panigrahi vd. (2007), FRP lamine kompozitlerin yapışkan lap makaslama birleştirmelerinde, delaminasyon hasar analizi üzerinde çalışmışlar ve yapışkan tabakadaki düzlem gerilimlerinden üç boyutlu sonlu eleman analizi gerçekleştirmişlerdir. Ara laminar kesme gerilmeleri ve delaminasyon mukavemetinin etkileri üzerinde durmuşlardır. Zhang (2013), deneysel alanda köpük çekirdekli sandviç panellerin, yarı statik üç noktalı eğilme hasar davranışı incelemişler ve sonra da FEM değerleri ile karşılaştırmışlardır. Çekirdek hasarı, yüz tabakası hasarı, arayüz hasarı, çekirdek çatlaması ve çekirdek kırma gibi bileşenlerde farklı hatalar, ABAQUS açık paketinin FEM simülasyonları ile açıklanmıştır. Swanson ve Kim (2003), CFRP kaplamaları ve köpük çekirdek sandviç yapılarının tasarımı üzerinde, deneysel ve FEM değerleri kullanarak bükülme etkisi ve sertlik gibi temas yükleri altında çalışmışlardır. Taşkaya (2017), St 37 levha çeliklerinde basınca bağlı levhaların mesnetlere göre tabakalarındaki mekanik gerilmelerin etkisini incelemiştir. Gür vd. (2017a), Ansys yazılımında farklı sicaklık ve gerilme parametrelerinde Al malzemesi ile SİC metal matrisli kompozitin sürünme uzaması hareketi ile elastik gerilmeler arasındaki ilişkilendirmeleri araştırmışlardır. Taşkaya vd. (2018), Ansys yazılımında sonlu elemanlar yöntemine göre, St 70 çatı kafes çeliğinin St 37 çatı kafes çeliğine göre, kiriş eksenlerindeki hem kuvvet hem de moment etkisine göre deformasyon ve vektörel gerilmelerin arttığını gözlemlemişlerdir. Polat vd. (2017), elastik yarı sonsuz düzleme oturan ve rijit iki blok ile yüklenmiş fonsiyonel derecelendirilmiş sürekli temas probleminin sonlu elemanlar yöntemi ile analizini incelemişlerdir. Polat vd. (2018), elastik yarı sonsuz düzleme oturan ve rijit iki blok ile yüklenmiş homojen tabakada sürekli temas probleminin karşılaştırmalı analizini araştırmışlardır. Taşkaya (2018), izotropik bir çelik malzemeye sahip 3D kafes çatı modeline, farklı yük ve sabit basınç uygulayarak, kiriş eksenlerindeki, deformasyon, mekanik ve elastik gerilme analizlerini araştırmıştır. Gür vd. (2017b) izotropik bir çelik malzemeyi 3 boyutlu kafes çatı olarak tasarlayarak, sonlu elemanlar yöntemine göre farklı yükler doğrultusunda kiriş 
eksenlerindeki mekanik gerilme etkilerini araştırmışlardır.

\section{Materyal Ve Metot}

\subsection{Modelin Ankastre Mesnet Olarak Tanımlanmnas}

İlk adım olarak düz ankastre mesnetli sandviç kompozit malzemeyi Ansys 12.0 paket programına mekanik analiz yapılacağ 1 için "structural"(yapı) olarak tanımlanır. Kompozit malzeme için element seçimi yapılır. Katı model çalışılacağı için Ansys programından "solid

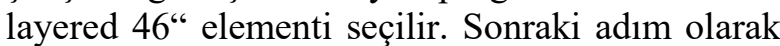
sandvic kompozit malzemenin Tablol'de gösterilen üst tabaka, alt tabaka ve çekirdek (köpük) tabakasının reel sabit numarası, tabaka sayıs1, oryantasyon açısı ve kalınlığı girilir.

Tablo 1. Sandviç kompozit tabakaların parametreleri

\begin{tabular}{ccccc}
\hline Malzeme Bölümü & $\begin{array}{c}\text { Reel Sabit } \\
\text { Numarası }\end{array}$ & $\begin{array}{c}\text { Tabaka } \\
\text { Sayısı }\end{array}$ & $\begin{array}{c}\text { Oryantasyon } \\
\text { Açısı }\end{array}$ & Kalınlık \\
\hline Üst Tabaka & 1 & 1 & 0 & $500 \mathrm{~mm}$ \\
\hline Alt Tabaka & 2 & 1 & 0 & $500 \mathrm{~mm}$ \\
\hline Çekirdek (köpük) & 3 & 1 & 0 & $500 \mathrm{~mm}$ \\
\hline
\end{tabular}

Sandviç kompozit malzemenin üst tabaka, alt tabaka ve çekirdek tabakasının Tablo 2'deki mekanik özellikleri Ansys 12.0 paket programına tanımlanır. Üst tabaka ve alt tabakalar ortotopik bir malzeme olduğu için sisteme malzemenin mekanik özellikleri tanımlanır. Çekirdek (köpük) tabakası izotropik malzeme olduğu için izotropik mekanik özellikler tanımlanır.

Tablo 2. Sandviç kompozit tabakaların mekanik özellikleri

\begin{tabular}{cccccccccc}
\hline Malzeme Bölümü & $\begin{array}{c}\text { Ex } \\
(\mathbf{M P a})\end{array}$ & $\begin{array}{c}\text { Ey } \\
(\mathbf{M P a})\end{array}$ & $\begin{array}{c}\text { Ez } \\
(\mathbf{M P a})\end{array}$ & Prxy & Pryz & Prxz & $\begin{array}{c}\text { Gxy } \\
(\mathbf{M P a})\end{array}$ & $\begin{array}{c}\text { Gyz } \\
(\mathbf{M P a})\end{array}$ & $\begin{array}{c}\text { Gxz } \\
(\mathbf{M P a})\end{array}$ \\
\hline Üst Tabaka & 23200 & 9000 & 9000 & 0.4 & 0.2 & 0.4 & 4000 & 4000 & 4000 \\
\hline Alt Tabaka & 19750 & 8500 & 8500 & 0.15 & 0.2 & 0.15 & 4500 & 4500 & 4500 \\
\hline Çekirdek (köpük) & 300 & & & 0.38 & & & & &
\end{tabular}

Sandviç kompozit tabakasının sınır ölçüleri Tablo 3'deki gibi sisteme girilerek model oluşturulur.

Tablo 3. Sandviç kompozit tabakanın model sınır ölçüleri

\begin{tabular}{ccccccc}
\hline Malzeme Bölümü & $\begin{array}{c}\mathbf{X}_{\mathbf{1}} \\
(\mathbf{m m})\end{array}$ & $\begin{array}{c}\mathbf{X}_{\mathbf{2}} \\
(\mathbf{m m})\end{array}$ & $\begin{array}{c}\mathbf{Y}_{\mathbf{1}} \\
(\mathbf{m m})\end{array}$ & $\begin{array}{c}\mathbf{Y}_{\mathbf{2}} \\
(\mathbf{m m})\end{array}$ & $\begin{array}{c}\mathbf{Z}_{\mathbf{1}} \\
(\mathbf{m m})\end{array}$ & $\begin{array}{c}\mathbf{Z}_{\mathbf{2}} \\
(\mathbf{m m})\end{array}$ \\
\hline Üst Tabaka & 0 & 500 & 10 & 15 & -150 & 150 \\
\hline Alt Tabaka & 0 & 500 & -12.9 & -15 & -150 & 150 \\
\hline Çekirdek (köpük) & 0 & 500 & -12.9 & 10 & -150 & 150 \\
\hline
\end{tabular}

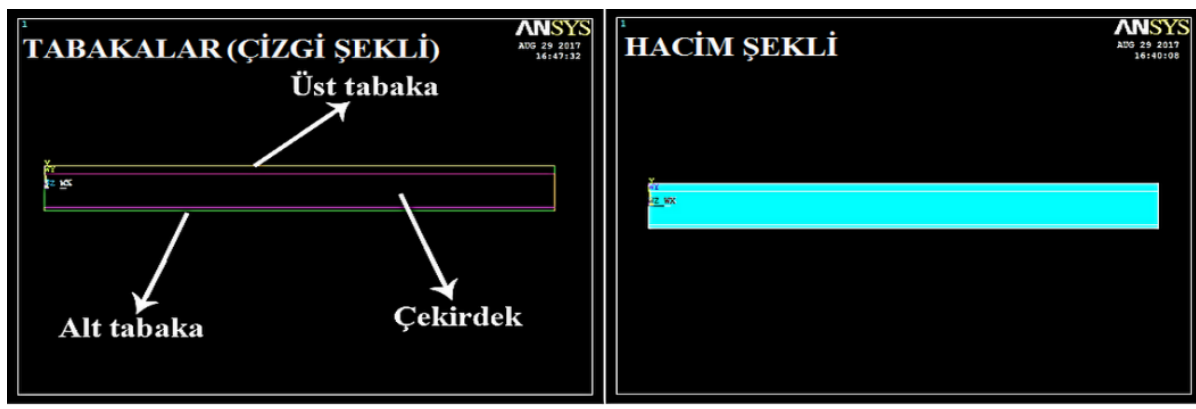

Şekil 1. Sandviç kompozit tabakanın modellenmesi 
Ansys yazılımında, modelin mekanik özelliklerini birbirine yapıştırma komutu olarak "Glue Volumes" modülü kullanılır. Sonraki işlem adımı olarak sistem başlangıcında Tablo 2'deki model parametrelerini üst tabaka, alt tabaka ve çekirdek tabakasını tek tek seçerek modele tanımlama işlemi yapılır.

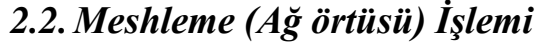

Sandviç kompozit malzeme modelinin ilk önce üst tabaka, sırasiyla alt tabaka ve çekirdek tabaka seçilerek mesh tanımlama işlemi yapılır ve ağ örtüsü sağlanmış olur. Buradaki amaç, mekanik simülasyon dağılımların birbirleriyle teması sağlanarak çözümleme yapılır.

\subsection{Mesnetleme ve sandviç tabakaya basınç uygulama işlemi}

Sandviç kompozit modelin sağ ve sol mesnetlerden üst, alt ve çekirdek tabakanın tamamı seçilerek ankastre mesnetleme şeklinde model sabitlenir ve üst tabakadan $4 \mathrm{MPa}$ basınç altında bir yük uygulanarak model çözümlendirilir (Şekil 3).
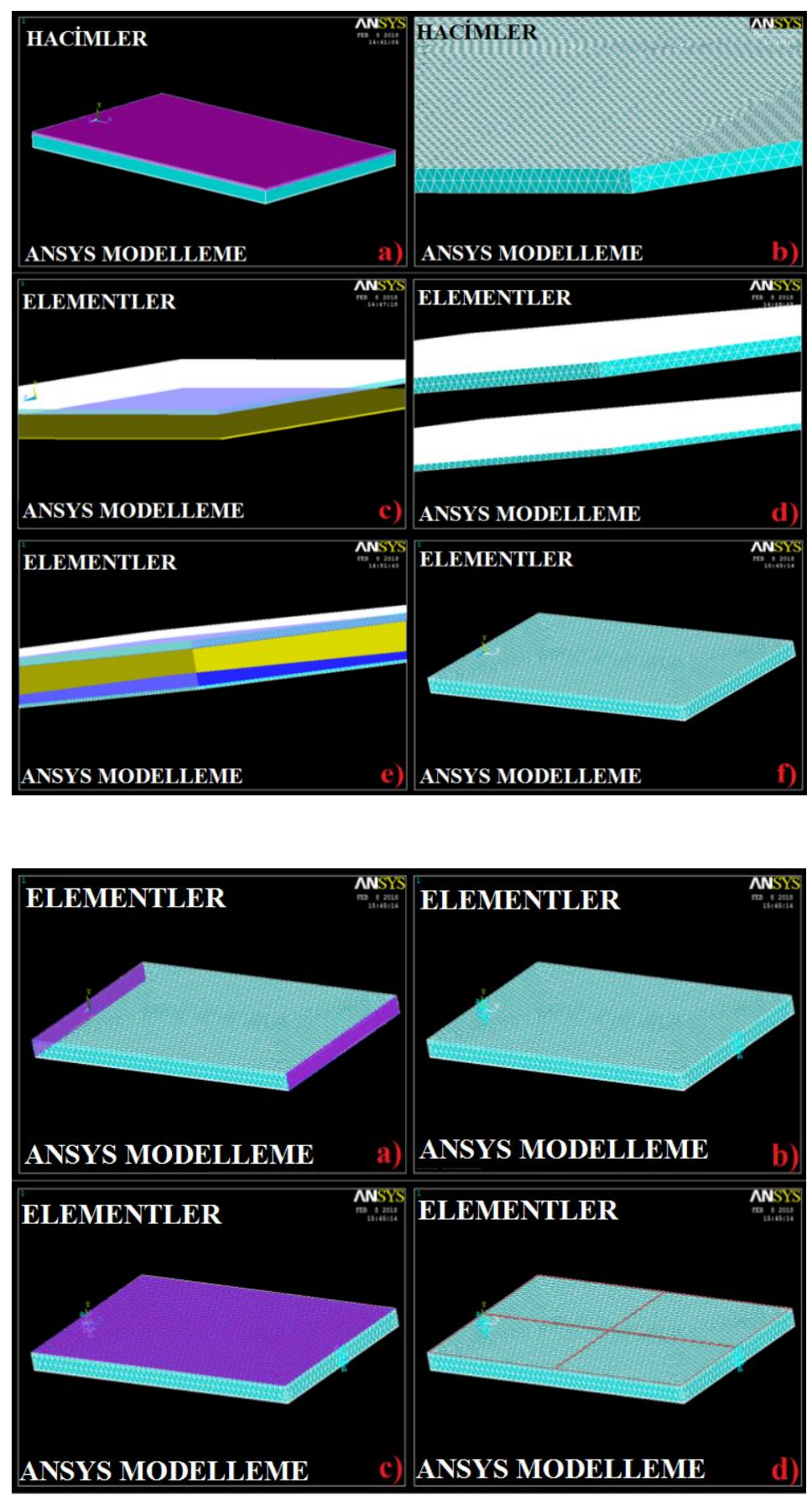

Şekil 2. Sandviç kompozit tabakanın meshleme aşamaları a) Üst tabakanın mesh ağının tanımlanması, b) Üst tabakanın mesh ağı, c) Alt tabakanın mesh ağının tanımlanması, d) Alt tabakanın mesh ağı, e) Çekirdek tabakasının mesh ağının tanımlanması ve f) Çekirdek tabakanın mesh ağı
Şekil 3. Sandviç kompozit tabakanın a ve b) sağ ve sol mesnetlerden ankastre mesnet tanımlaması, c ve d) Üst tabakaya basınç uygulama işlemi 


\subsection{Modelin çizgisel mesnetlenmesi}

Sandviç kompozit modelin çizgisel olarak mesnetlenmesi işleminde düz ankastre modeldeki işlemlerin aynısı sırasıyla Ansys programına tanımlanır. Sadece model oluşturulduktan sonra mesnetleme işlemine gelindiğinde Şekil 4'de gösterildiği gibi sağ ve sol üst tabaka kenar çizgileri seçilerek model çizgisel olarak mesnetlenmiş olur ve üst plakaya aynı şekilde 4 MPa basınç uygulanarak çizgisel mesnetli model çözümlendirilir.

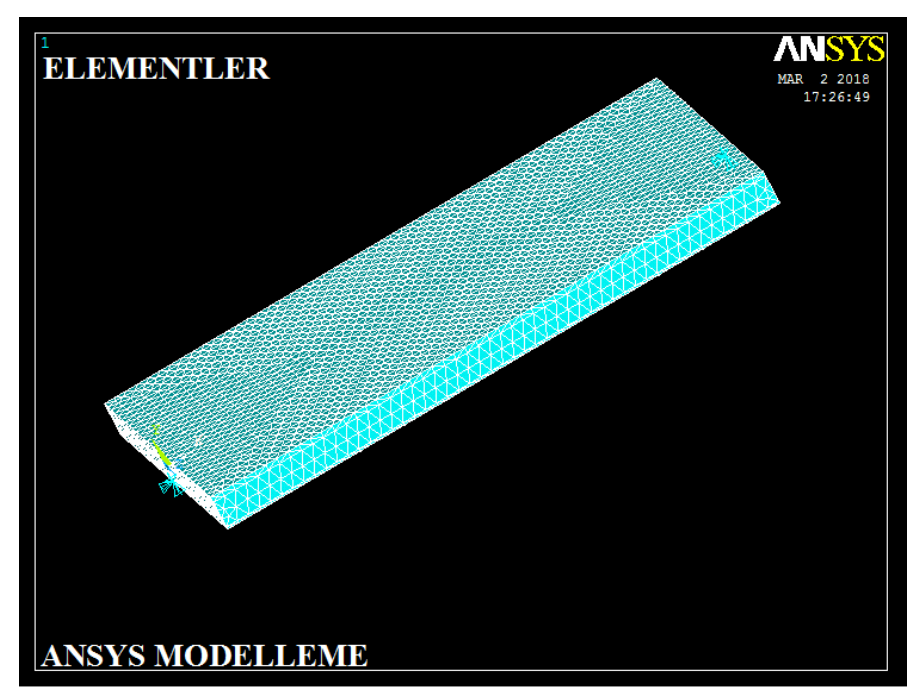

Şekil 4. Sandviç kompozit tabakanın çizgisel mesnetlenmesi

\subsection{Sandviç kompozit tabakanın radyal modellenmesi ve meshleme işlemi}

Radyal ankastre mesnetli sandviç modelin oluşturulmasındaki işlemler düz ankastre mesnetli plakalı sandviç kompozit modelin aşamalarındaki gibi Tablo 1 ve Tablo 2 parametreleri ve mekanik özellikleri Ansys programına tanımlanır. Model oluşumunda sınır koşulları radyal model olduğu için belirlenen ölçüler doğrultusunda Tablo 4'e göre sisteme tanımlanır ve $7^{0}$ lik oryantasyon açısına sahip radyal model oluşturulur (Şekil 5). Daha sonra modele düz plakalı sandviç modelde olduğu gibi ayrı ayrı tabakalara ağ yapısı tanımlanarak meshleme işlemi yapılır (Şekil 6).

Tablo 4. Radyal tabakalı sandviç kompozit modelin sınır parametreleri

\begin{tabular}{ccccccc}
\hline Malzeme Bölümü & $\begin{array}{c}\text { Dış } \\
\text { yarıçap }\end{array}$ & $\begin{array}{c}\text { İsteğe bağlı } \\
\text { iç yarıçap }\end{array}$ & $\begin{array}{c}\mathbf{Z}_{\mathbf{1}} \\
\text { koordinatı }\end{array}$ & $\begin{array}{c}\mathbf{Z}_{\mathbf{2}} \\
\text { koordinatı }\end{array}$ & $\begin{array}{c}\text { Başlangıçç } \\
\text { açısı }\end{array}$ & $\begin{array}{c}\text { Bitiş } \\
\text { açısı }\end{array}$ \\
\hline Üst Tabaka & 4005 & 4000 & 0 & 500 & 0 & 7 \\
\hline Alt Tabaka & 4030 & 4027.9 & 0 & 500 & 0 & 7 \\
\hline Çekirdek (köpük) & 4027.9 & 4005 & 0 & 500 & 0 & 7 \\
\hline
\end{tabular}

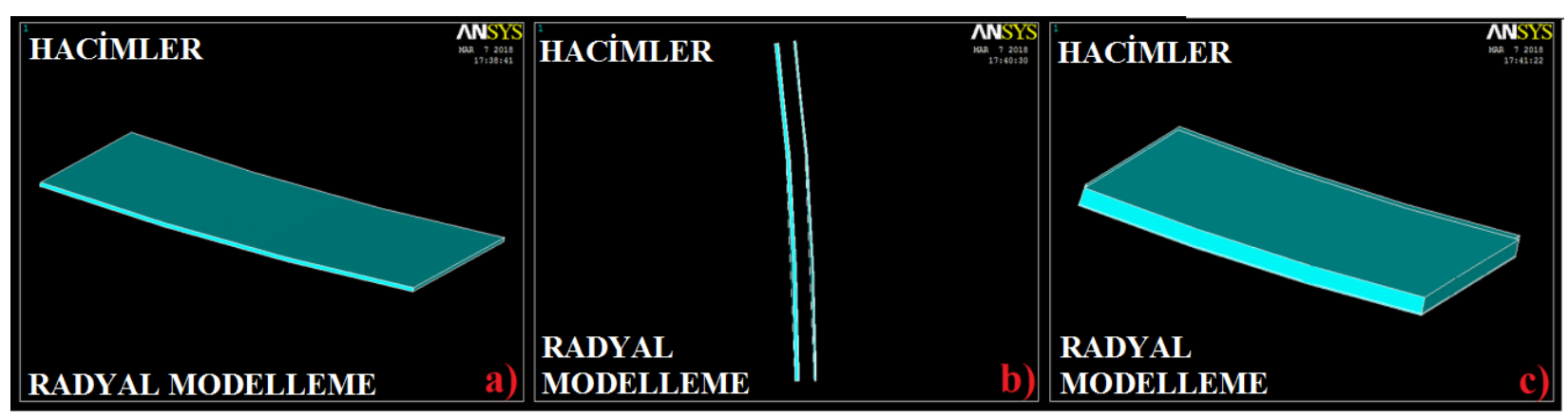

Şekil 5. Radyal tabakanın modellenmesi a) üst tabaka, b) alt tabaka ve c) çekirdek tabaka ve modelin bütün hali 


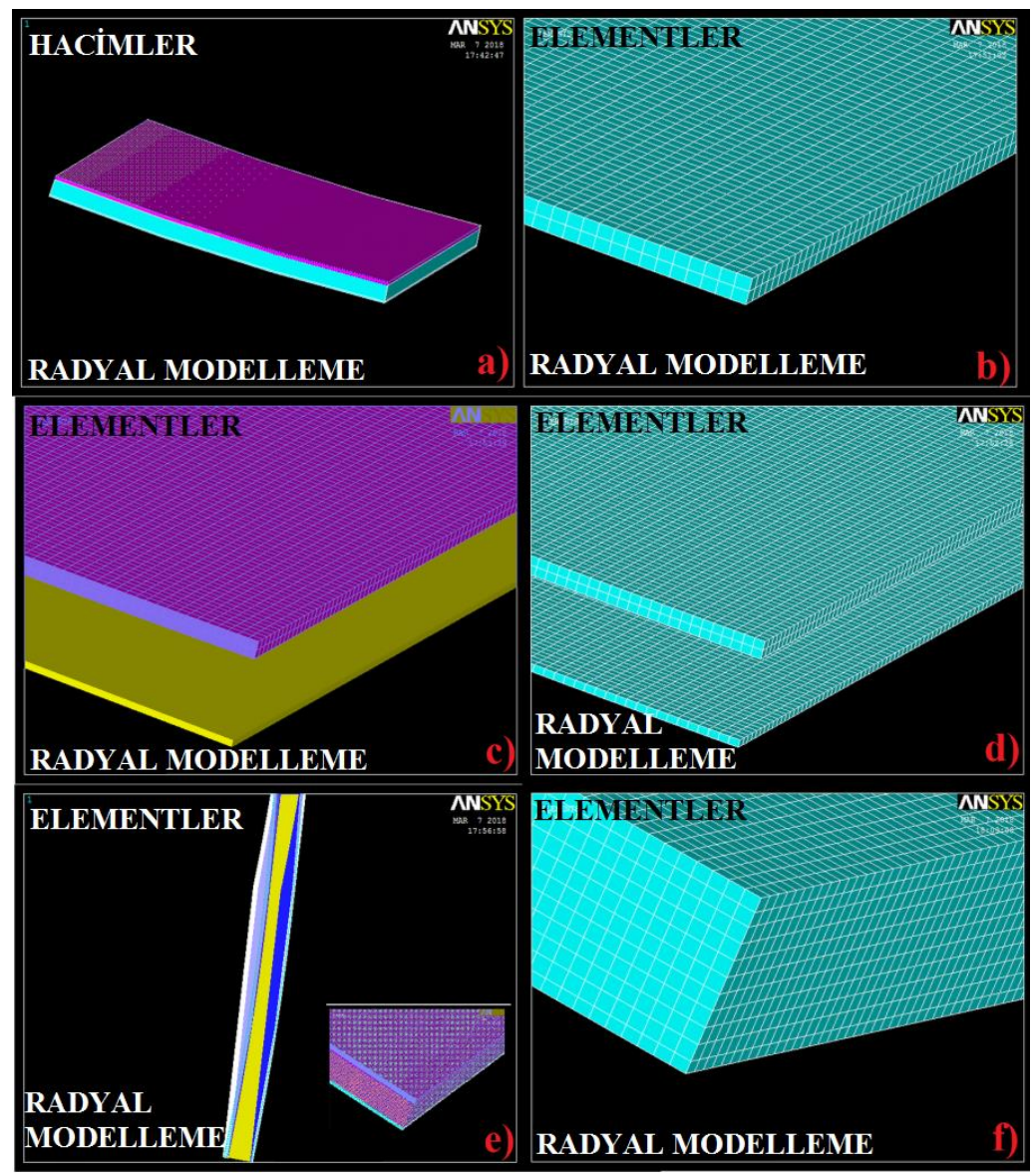

Şekil 6. Radyal tabakanın meshlenmesi a ve b) Üst radyal tabakanın mesh ağının tanımlanması ve mesh işlemi, c ve d) Alt radyal tabakanın mesh ağının tanımlanması ve mesh işlemi, e ve f) Çekirdek radyal tabakanın mesh ağının tanımlanması ve mesh işlemi, modelin bütün hali

\subsection{Mesnetleme ve radyal sandviç tabakaya basınç uygulama işlemi}

Radyal sandviç kompozit modelin ankastre olarak mesnetlenmesi işleminde düz ankastre sandviç kompozit modeldeki işlemlerin aynısı sırasıyla
Ansys programına tanımlanır. Model izotropik görünümden sağ ve sol üst, alt ve çekirdek tabakaların hepsi seçilerek ankastre mesnetlenmiş olur ve üst plakaya aynı şekilde $4 \mathrm{MPa}$ basınç uygulanarak model çözümlendirilir (Şekil 7).

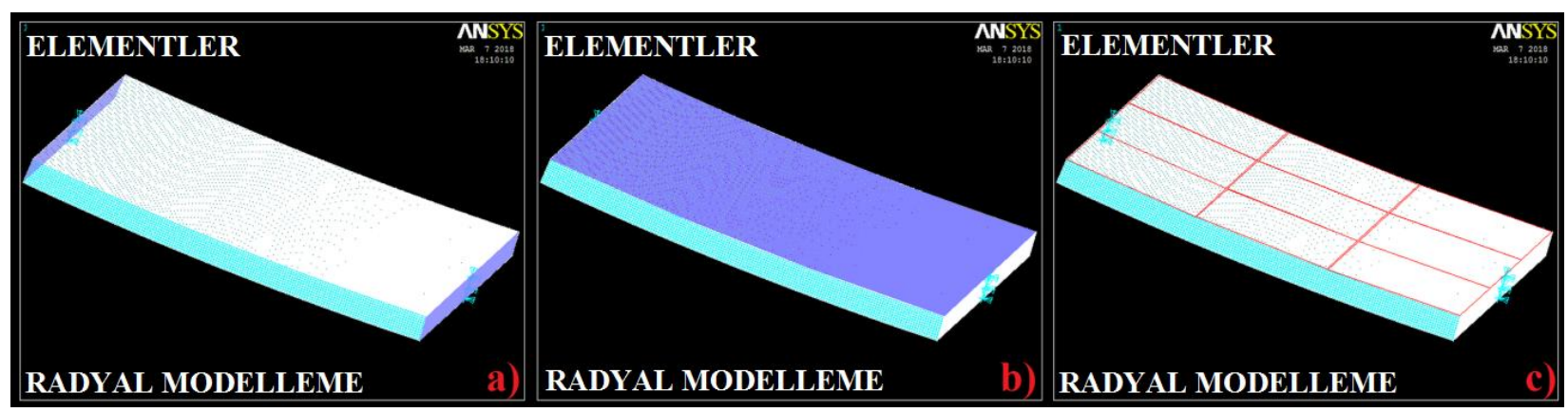

Şekil 7. Radyal sandviç tabakanın a) Sağ ve sol mesnetlerden ankastre mesnetlenmesi, b) Üst tabakaya basınç tanımlama ve c) Üst tabakaya basıncın uygulanması

\subsection{Radyal modelin çizgisel mesnetlenmesi}

Radyal sandviç modelin çizgisel olarak mesnetlenmesi işleminde düz çizgisel modeldeki işlemlerin aynısı sırasıyla Ansys programına tanımlanır. Sadece model oluşturulduktan sonra mesnetleme işlemine gelindiğinde Şekil 8'de görüldüğü gibi sağ ve sol üst tabaka kenar çizgileri seçilerek model çizgisel olarak mesnetlenmiş olur ve üst plakaya aynı şekilde 4 
MPa basınç uygulanarak çizgisel mesnetli model çözümlendirilir.

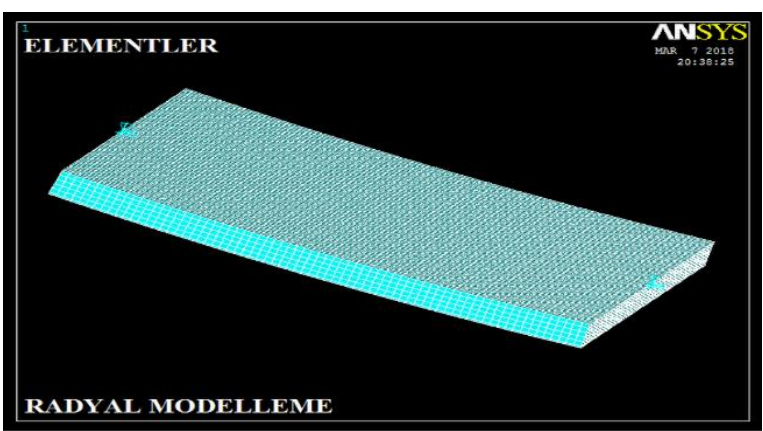

Şekil 8. Radyal sandviç kompozit tabakanın çizgisel mesnetlenmesi

\section{Bulgular ve Tartışma}

\subsection{Düz ankastreli sandviç kompozitin çözümlenmesi}

Düz ankastreli sandviç kompozit tabakanın basınca bağlı olarak çözümlenmesi sonucunda 52891 eleman ve 10882 node (düğüm sayıs1) sayısı oluşmuştur. Şekil 9'da sandviç tabakanın deformasyon şekil değişimi ve vektör analizi incelenmiştir. Şekil 10'da ise eksenlere bağlı stres gerilim analizleri yapılmıştır.

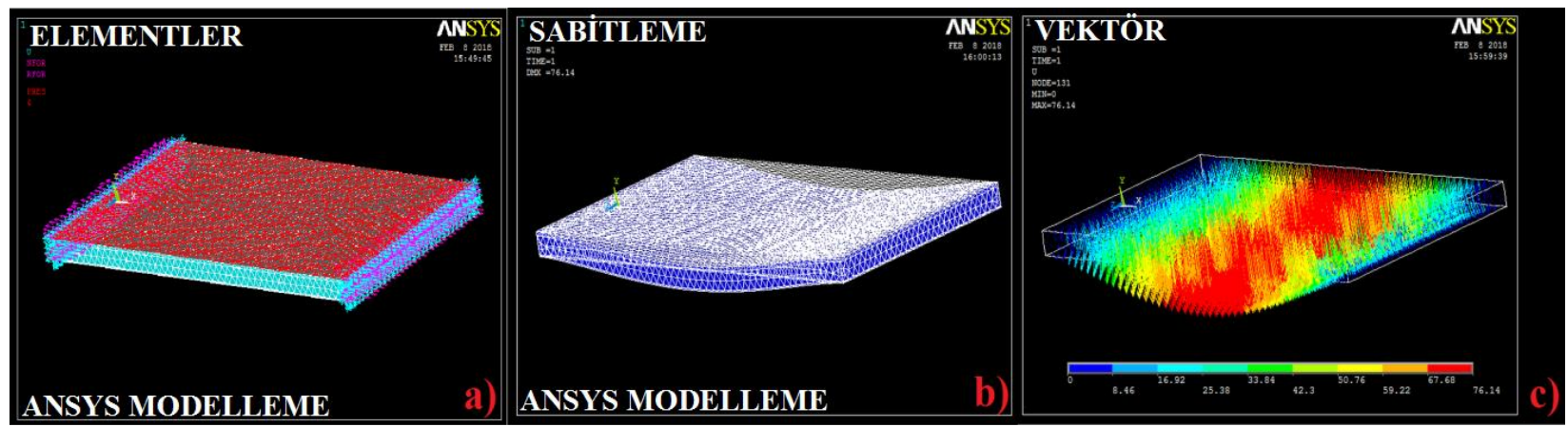

Şekil 9. Düz ankastreli sandviç kompozit tabakanın a) Modelin çözümlenmesi, b) Deformasyon şekil değişimi ve c) Bileşke vektör analizi

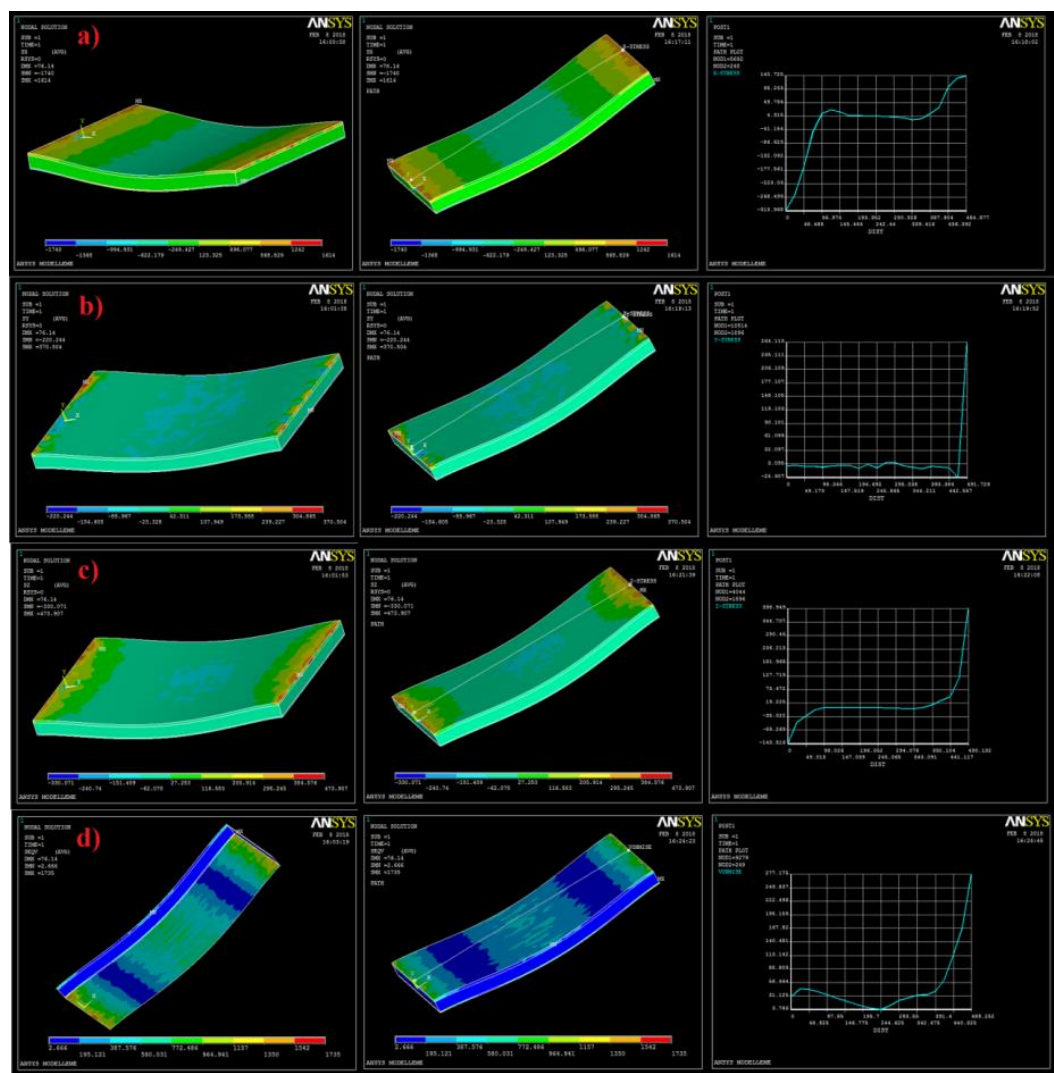

Şekil 10. Düz ankastreli sandviç kompozit tabakanın a) X eksenindeki stress gerilim analizi, b) $\mathrm{Y}$ eksenindeki stress gerilim analizi, c) Z eksenindeki stress gerilim analizi ve d) Von mises gerilim analizi 
Şekil 11'de sandviç tabakada meydana gelen toplam mekanik gerilim dağılımları simulize edilmiştir. Burada meydana gelen gerilimler grafik analizlerle incelenmiştir.

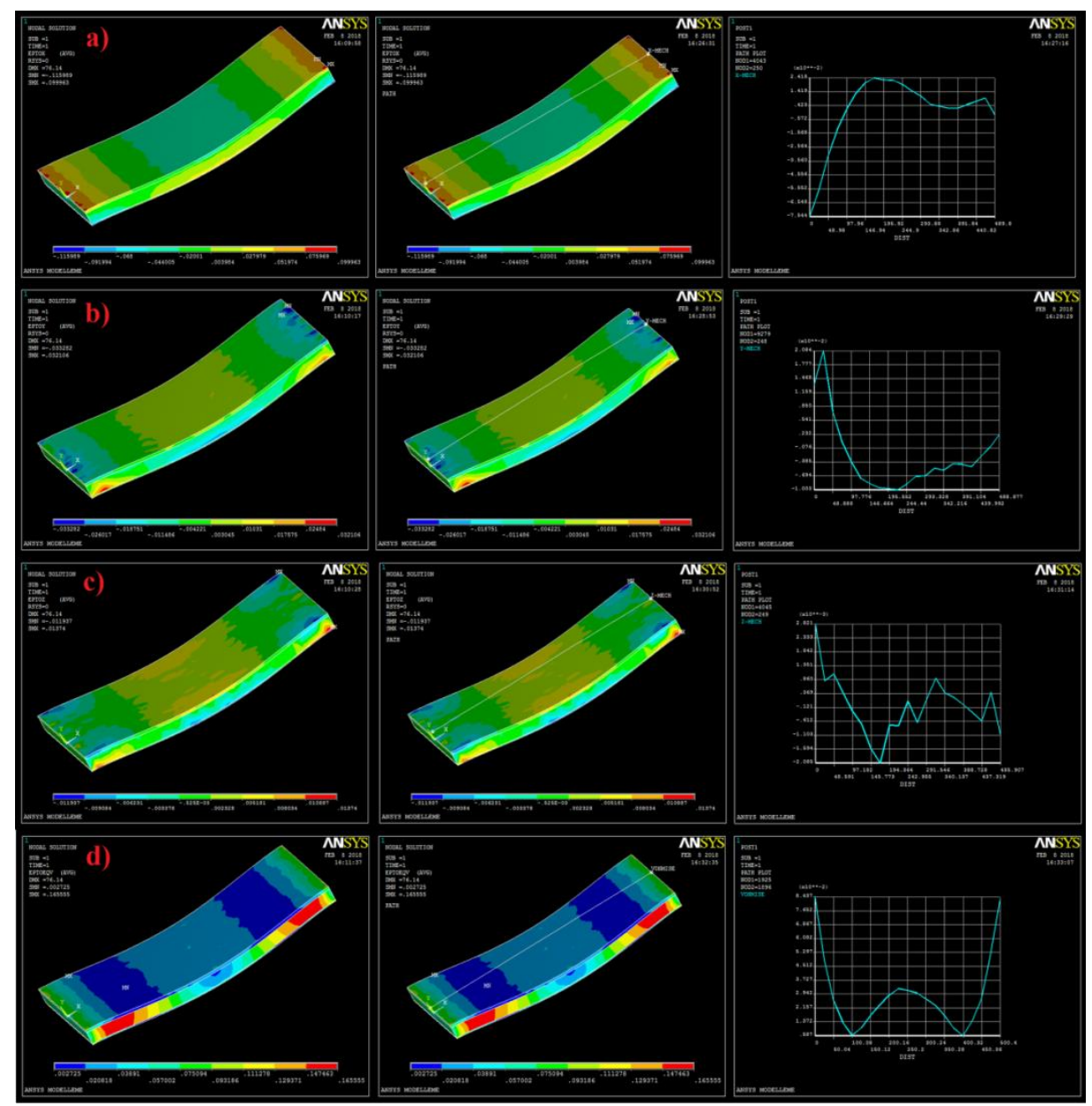

Şekil 11. Düz ankastreli sandviç kompozit tabakanın a) X eksenindeki toplam mekanik gerilim analizi, b) Y eksenindeki toplam mekanik gerilim analizi, c) Z eksenindeki toplam mekanik gerilim analizi ve d) Von mises toplam mekanik analizi

\subsection{Düz çizgisel sandviç kompozitin çözümlenmesi}

Düz çizgisel sandviç kompozit tabakanın basınca bağl1 olarak çözümlenmesi sonucunda Şekil 12'de sandviç tabakanın deformasyon şekil değişimi ve vektör analizi incelenmiştir. Şekil 13'de ise eksenlere bağlı stres gerilim analizleri yapılmıştır. Şekil 14'de sandviç tabakada meydana gelen toplam mekanik gerilim dağılımları simulize edilmiştir. Burada meydana gelen gerilimler grafik analizlerle incelenmiştir.

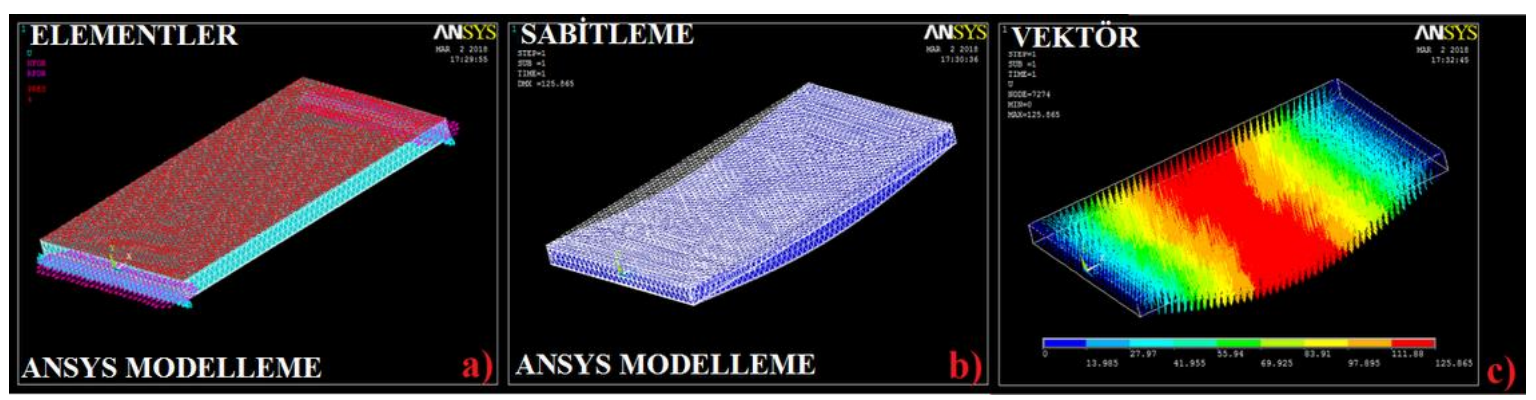

Şekil 12. Düz çizgisel sandviç kompozit tabakanın a) Modelin çözümlenmesi, b) Deformasyon şekil değişimi ve c) Bileşke vektör analizi 

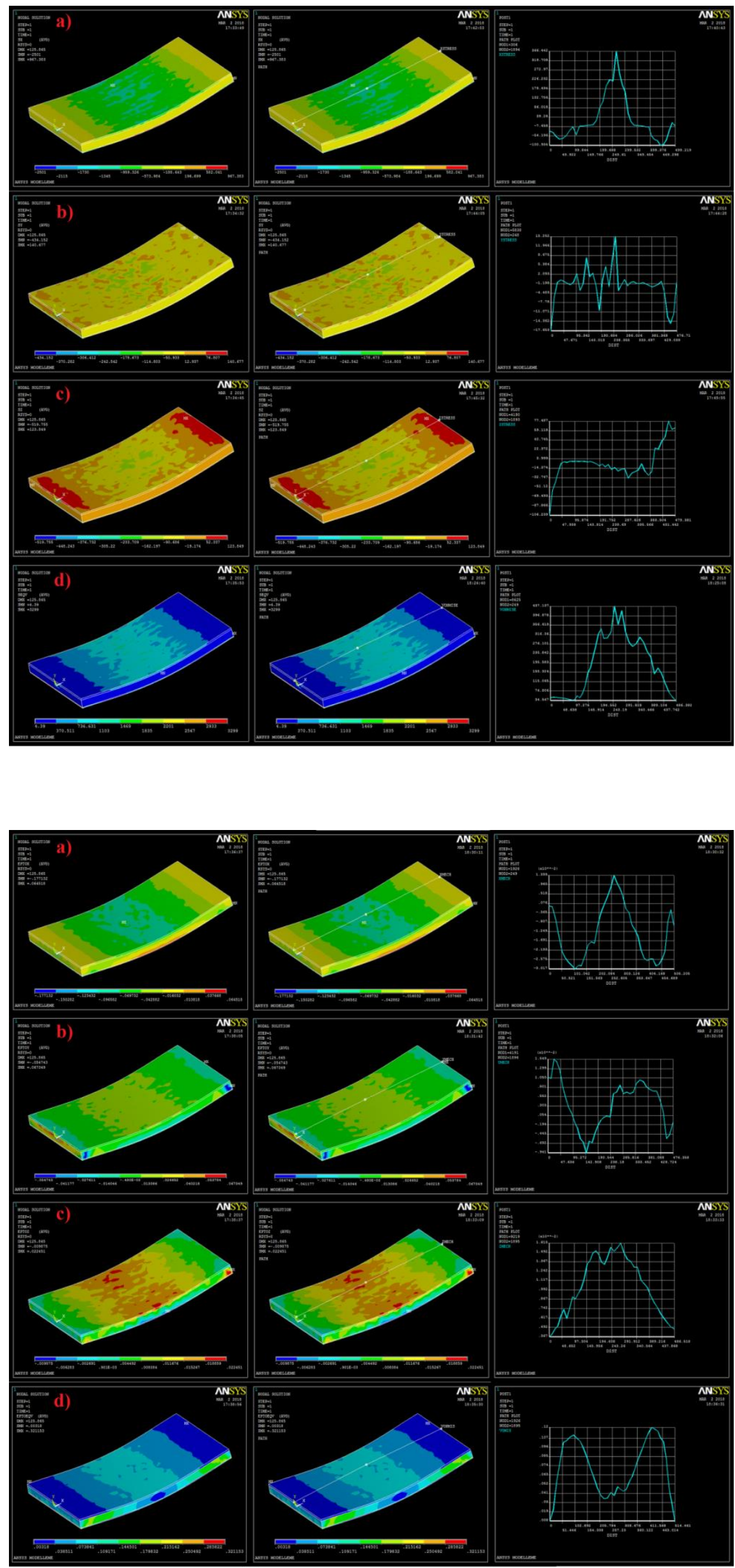

Şekil 13. Düz çizgisel sandviç kompozit tabakanın a) $\mathrm{X}$ eksenindeki stress gerilim analizi, b) $\mathrm{Y}$ eksenindeki stress gerilim analizi, c) $\mathrm{Z}$ eksenindeki stress gerilim analizi ve d) Von mises gerilim analizi

Şekil 14. Düz çizgisel sandviç kompozit tabakanın a) $\mathrm{X}$ eksenindeki toplam mekanik gerilim analizi, b) $\mathrm{Y}$ eksenindeki toplam mekanik gerilim analizi, c) Z eksenindeki toplam mekanik gerilim analizi ve d) Von mises toplam mekanik analizi 


\subsection{Radyal ankastre sandviç kompozitin çözümlenmesi}

Radyal ankastreli sandviç kompozit tabakanın basınca bağlı olarak çözümlenmesi sonucunda
30672 eleman ve 36792 node (düğüm sayıs1) sayısı oluşmuş̧ur. Şekil 15'de sandviç tabakanın deformasyon şekil değişimi ve vektör analizi incelenmiştir. Şekil 16'da ise eksenlere bağlı stres gerilim analizleri yapılmıştır.

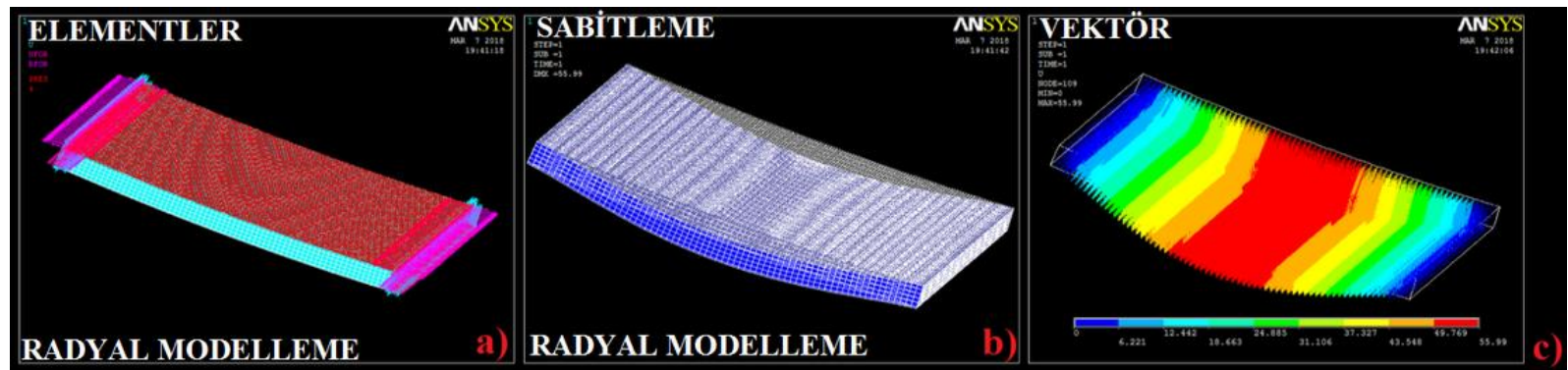

Şekil 15. Radyal ankastre sandviç kompozit tabakanın a) Modelin çözümlenmesi, b) Deformasyon şekil değişimi ve c) Bileşke vektör analizi

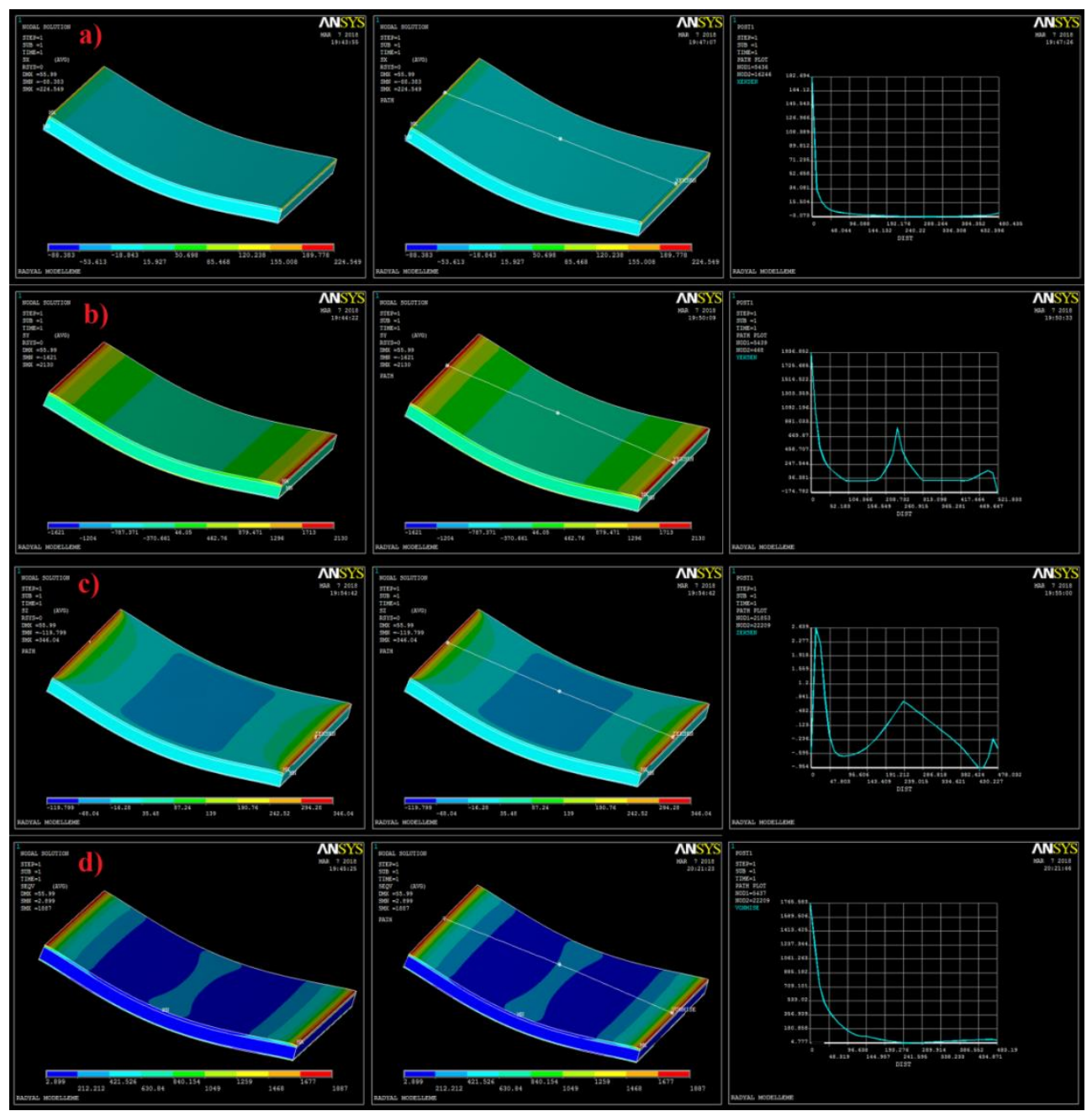

Şekil 16. Radyal ankastre sandviç kompozit tabakanın a) X eksenindeki stress gerilim analizi, b) Y eksenindeki stress gerilim analizi, c) Z eksenindeki stress gerilim analizi ve d) Von mises gerilim analizi

Şekil 17'de sandviç tabakada meydana gelen toplam mekanik gerilim dağılımları simulize edilmiştir. Burada meydana gelen gerilimler grafik analizlerle incelenmiştir. 


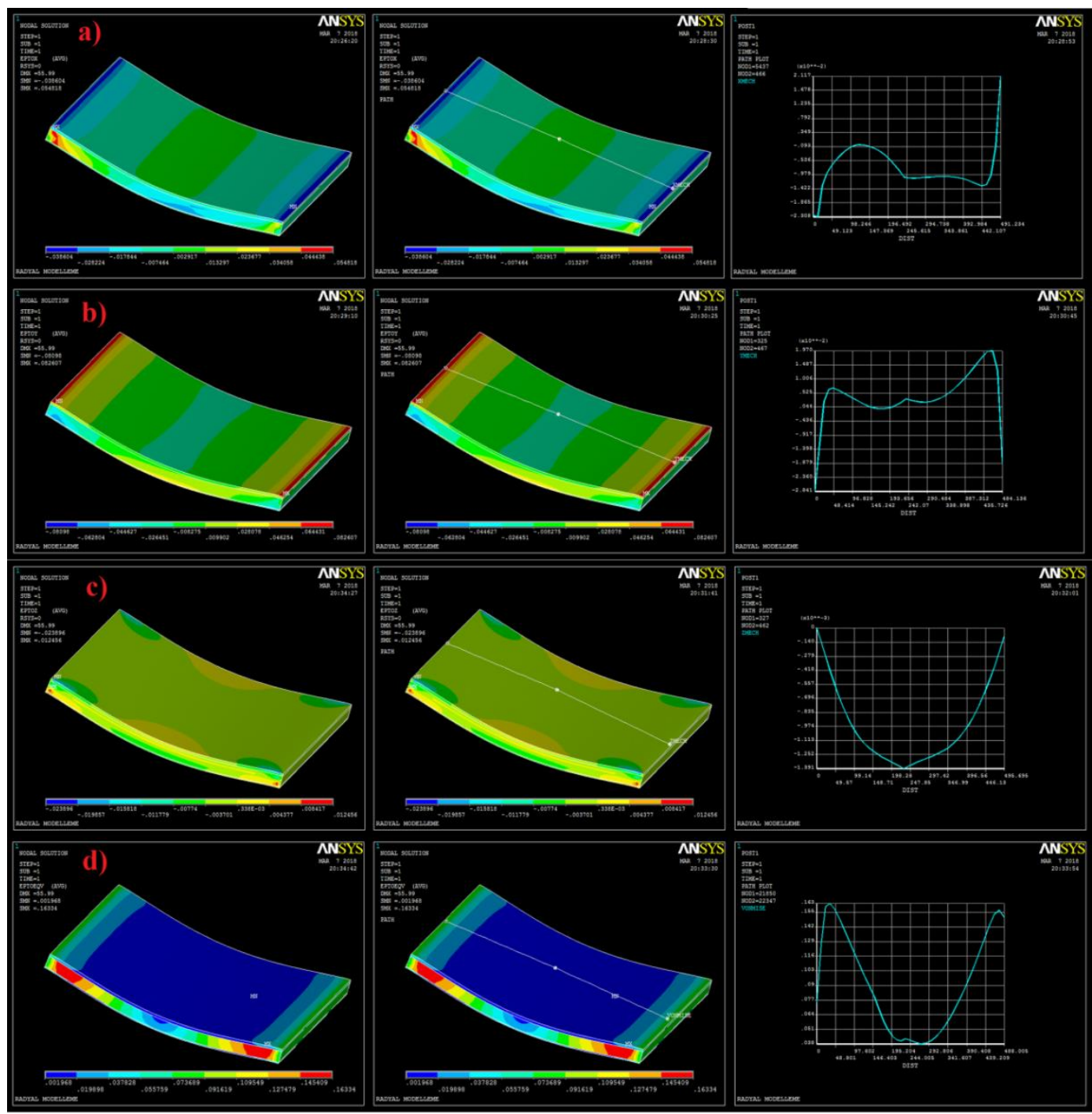

Şekil 17. Radyal ankastre sandviç kompozit tabakanın a) X eksenindeki toplam mekanik gerilim analizi, b) Y eksenindeki toplam mekanik gerilim analizi, c) Z eksenindeki toplam mekanik gerilim analizi ve d) Von mises toplam mekanik analizi

\subsection{Radyal çizgisel sandviç kompozitin çözümlenmesi}

Radyal çizgisel sandviç kompozit tabakanın basınca bağlı olarak çözümlenmesi sonucunda
Şekil 18'de sandviç tabakanın deformasyon şekil değişimi ve vektör analizi incelenmiştir. Şekil 19 'da ise eksenlere bağlı stres gerilim analizleri yapılmıştır.

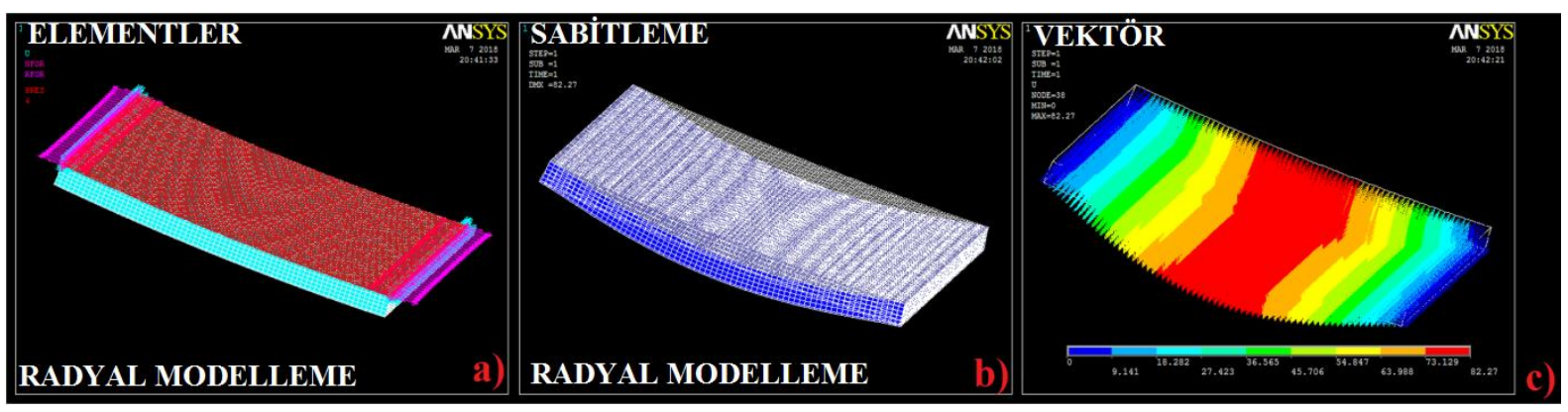

Şekil 18. Radyal çizgisel sandviç kompozit tabakanın a) Modelin çözümlenmesi, b) Deformasyon şekil değişimi ve c) Bileşke vektör analizi 


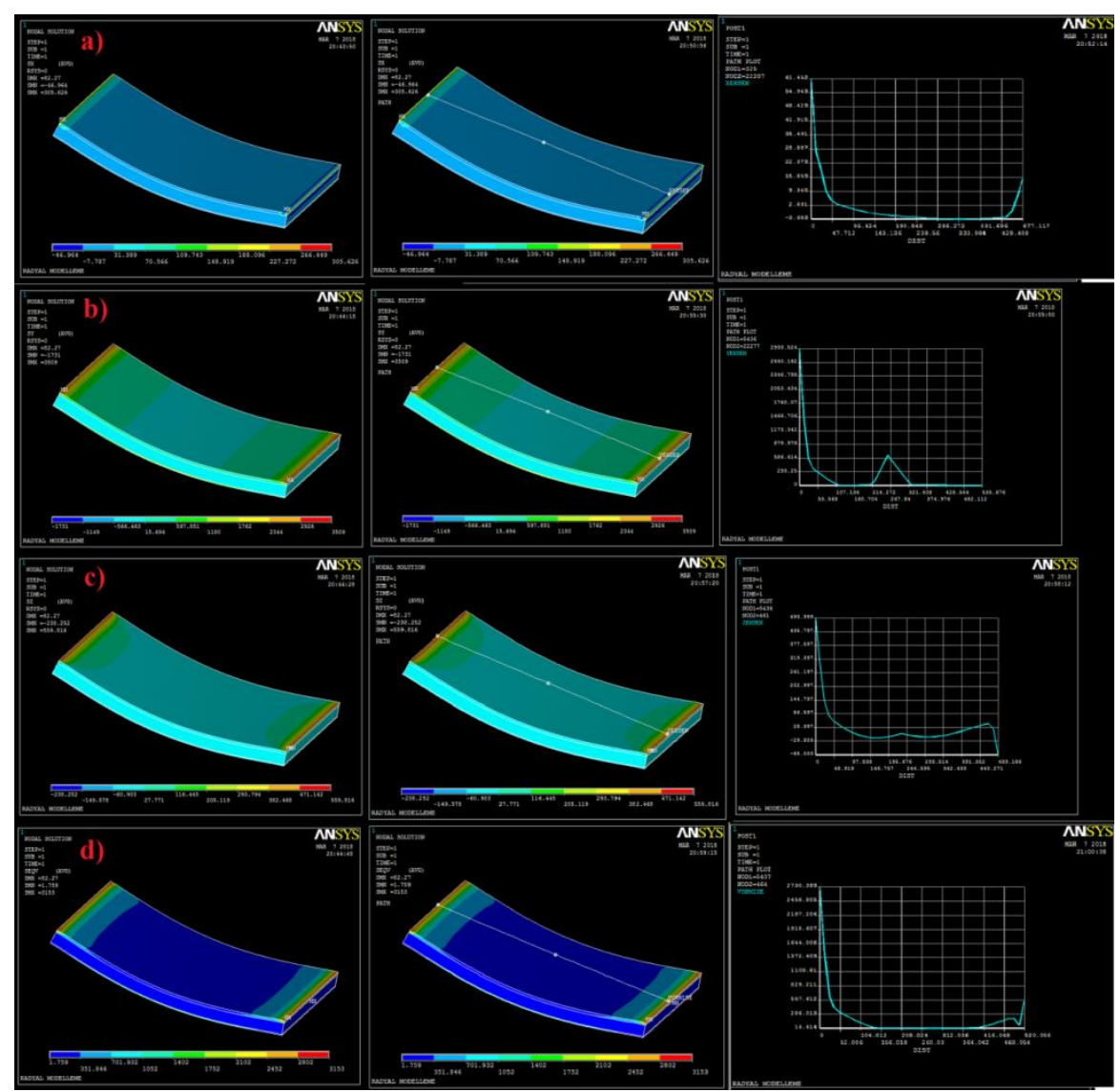

Şekil 19. Radyal çizgisel sandviç kompozit tabakanın a) $\mathrm{X}$ eksenindeki stress gerilim analizi, b) $\mathrm{Y}$ eksenindeki stress gerilim analizi, c) Z eksenindeki stress gerilim analizi ve d) Von mises gerilim analizi

Şekil 20'de sandviç tabakada meydana gelen toplam mekanik gerilim dağılımları simulize edilmiştir. Burada meydana gelen gerilimler grafik analizlerle incelenmiştir.
Tablo 5'de sandviç tabakalarda meydana gelen stres gerilim analizlerin simülasyon dağılım sonuçları verilmiştir.

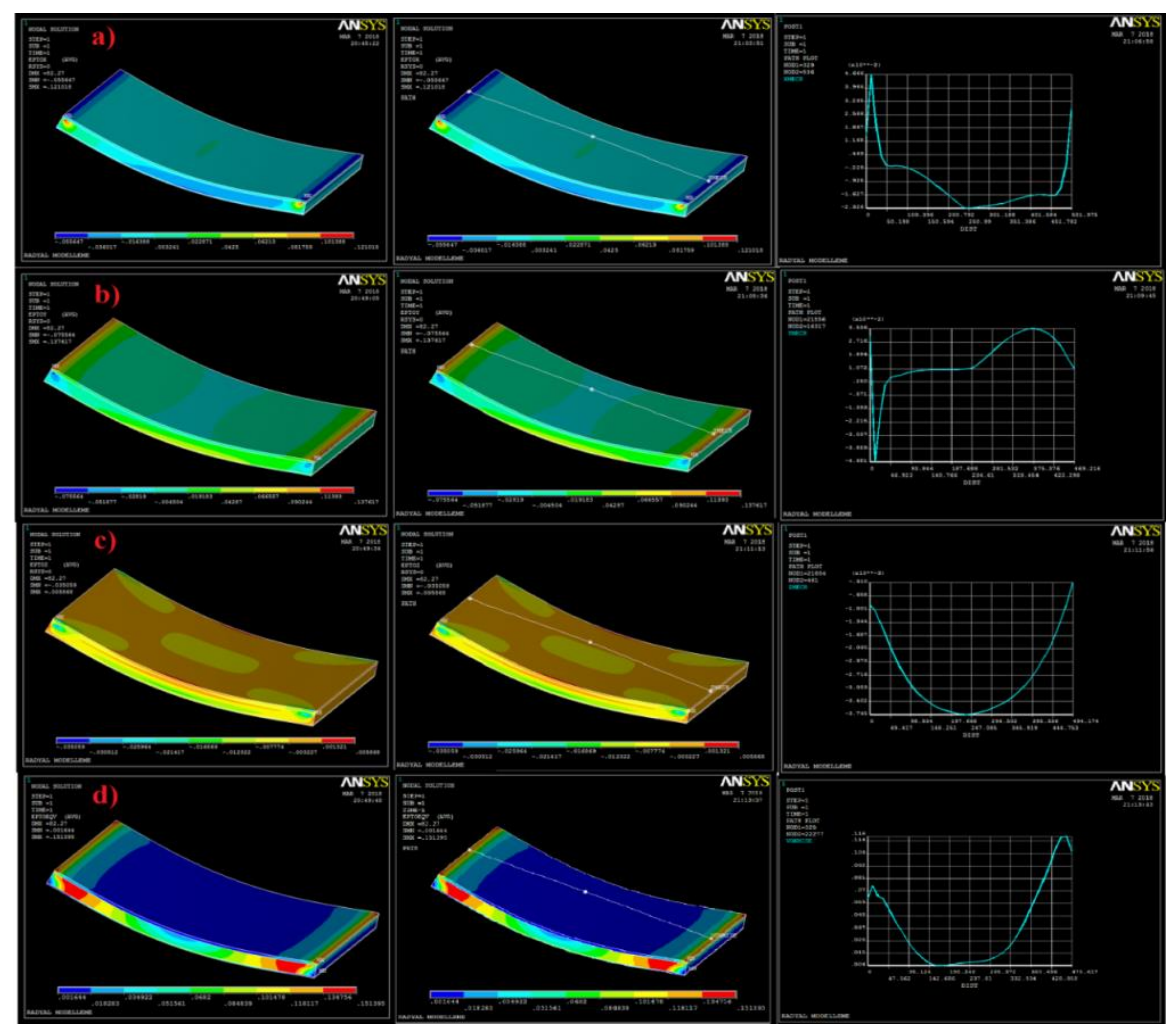

Şekil 20. Radyal çizgisel sandviç kompozit tabakanın a) $\mathrm{X}$ eksenindeki toplam mekanik gerilim analizi, b) Y eksenindeki toplam mekanik gerilim analizi, c) $\mathrm{Z}$ eksenindeki toplam mekanik gerilim analizi ve d) Von mises toplam mekanik analizi 


\section{Genel Sonuçlar ve Öneriler}

Analiz sonuçları 2 şekilde kıyaslandığı zaman;

- Geometri şekilleri aynı, mesnetleri farklı stres gerilim skala sonuçlarında, düz ankastreli mesnetin çeki oranlarının çizgisel mesnete göre artış gösterdiği ve bası oranlarının ise azalış gösterdiği incelenmiştir. Radyal ankastreli mesnetin çeki oranlarının çizgisel mesnete göre azaldığı fakat bası oranlarının ise $\mathrm{x}$ ekseninde arttığı, y ve z eksenlerinde azaldığ 1 görülmüsstür.

- Geometri şekilleri farklı, mesnetleri aynı stres gerilim skala sonuçlarında ise, radyal ankastreli mesnetin düz mesnete göre hem çeki ve hem de bası oranlarının y ekseninde arttığ 1 x ve z ekseninde azaldığ görülmüştür. Radyal çizgisel mesnetin düz mesnete göre, $x$ ekseninde çeki ve bas1 oranlarının azaldığı, y ekseninde arttığ $1, \mathrm{z}$ ekseninde ise çeki oranının arttığı bası oranının azaldığı görülmüştür. $\mathrm{Bu}$ sandviç kompozit tabakalar arasındaki mesafeye bağlı mekanik grafiksel gerilimler üst, orta ve alt dügüm noktalarından alınmıştır. Hem stres hem de toplam mekanik mesafeye bağlı gerilim grafiksel sonuçlar kıyaslandığı zaman, sandviç kompozitlerin yapısı gereği gerilimlerin anizotropi (Manning vd., 1993; Bannister vd., 1999) yani değişik farklı yönlenmelerin olduğu artış ve azalış yani titreşimli gerilmeler gözlemlenmiştir.

Sandviç tabakaların mesafeye bağlı toplam mekanik gerilim skala sonuçları mukayese edildiği zaman;

Geometri şekilleri aynı, mesnetleri farklı toplam mekanik skala gerilim sonuçlarında, düz ankastreli mesnetin çizgisel mesnete göre $\mathrm{x}$ eksenindeki çeki oranının arttığı, y ve $\mathrm{z}$ eksenlerinde ise azaldığı, bası oranlarının $\mathrm{x}, \mathrm{y}$ eksenlerinde azaldığı, $\mathrm{z}$ ekseninde ise arttığ gözlemlenmiştir. Radyal ankastreli mesnetin çeki oranlarının çizgisel mesnete göre $\mathrm{x}, \mathrm{y}$ eksenlerinde azaldı $\breve{1} 1$, $\mathrm{z}$ ekseninde ise arttığ bas1 oranlarının $\mathrm{x}, \mathrm{z}$ eksenlerinde azaldığı, $\mathrm{y}$ ekseninde ise arttığı gözlemlenmiştir.

Tablo 5. Sandviç kompozit tabakaların stres simülasyon dağımların sonuçları

\begin{tabular}{|c|c|c|c|c|c|}
\hline$E x$ & $\begin{array}{c}\sigma \mathbf{x} \\
(\mathbf{M P a})\end{array}$ & $\begin{array}{c}\sigma \mathbf{y} \\
(\mathbf{M P a})\end{array}$ & $\begin{array}{c}\sigma \mathbf{z} \\
(\mathbf{M P a})\end{array}$ & $\begin{array}{c}\text { Von Mises } \\
\text { Gerilme } \\
\text { (MPa ) } \\
\end{array}$ & $\begin{array}{l}\text { Vector } \\
\text { analizi }\end{array}$ \\
\hline $\begin{array}{c}\text { (Düz Tabaka, } \\
\text { Ankastre Mesnet) }\end{array}$ & $\begin{array}{l}1614 \mathrm{Mpa} \\
\text { (Çeki) } \\
1740 \mathrm{Mpa} \\
\text { (Basi) }\end{array}$ & $\begin{array}{l}\text { 370.504 Mpa } \\
\text { (Çeki ) } \\
220.244 \mathrm{Mpa} \\
\text { (Basi ) }\end{array}$ & $\begin{array}{l}\text { 473.907 Mpa } \\
\text { (Çeki) } \\
\text { 330.071 Mpa } \\
\text { (Bas1) }\end{array}$ & $\begin{array}{l}\text { 1735 Mpa } \\
\text { (Çeki) } \\
2.666 \mathrm{Mpa} \\
\text { (Basi) }\end{array}$ & $\begin{array}{c}76.14 \text { (çeki) } \\
0 \\
\text { (bası) }\end{array}$ \\
\hline $\begin{array}{c}\text { (Düz Tabaka, } \\
\text { Çizgisel Mesnet) }\end{array}$ & $\begin{array}{c}\text { 967.383 Mpa } \\
\text { (Çeki) } \\
2501 \mathrm{Mpa} \\
\text { (Bas1) } \\
\end{array}$ & $\begin{array}{c}\text { 140.677 Mpa } \\
\text { (Çeki ) } \\
\text { 434.152 Mpa } \\
\text { (Bas1 ) } \\
\end{array}$ & $\begin{array}{c}123.849 \mathrm{Mpa} \\
\text { (Çeki ) } \\
519.755 \mathrm{Mpa} \\
\text { (Bas1) } \\
\end{array}$ & $\begin{array}{l}\text { 3299 Mpa } \\
\text { (Çeki) } \\
4.39 \mathrm{Mpa} \\
\text { (Basi) } \\
\end{array}$ & $\begin{array}{c}125.865 \\
\text { (çeki) } \\
0 \\
\text { (bası) } \\
\end{array}$ \\
\hline $\begin{array}{l}\text { म+16 } \\
\text { (Radyal Tabaka, } \\
\text { Ankastre Mesnet) }\end{array}$ & $\begin{array}{c}\text { 224.549 Mpa } \\
\text { (Çeki) } \\
88.383 \mathrm{Mpa} \\
\text { (Bas1) } \\
\end{array}$ & $\begin{array}{c}2130 \mathrm{Mpa} \\
\text { (Çeki) } \\
1621 \mathrm{Mpa} \\
\text { (Basi) } \\
\end{array}$ & $\begin{array}{c}346.04 \mathrm{Mpa} \\
\text { (Çeki) } \\
119.799 \mathrm{Mpa} \\
\text { (Bas1) } \\
\end{array}$ & $\begin{array}{l}1887 \mathrm{Mpa} \\
\text { (Çeki) } \\
2.899 \mathrm{Mpa} \\
\text { (Basi) } \\
\end{array}$ & $\begin{array}{c}55.99 \text { (çeki) } \\
0 \\
\text { (basi) }\end{array}$ \\
\hline $\begin{array}{l}\text { (Radyal Tabaka, } \\
\text { Çizgisel Mesnet) }\end{array}$ & $\begin{array}{l}\text { 305.626 Mpa } \\
\text { (Çeki) } \\
\text { 46.964 Mpa } \\
\text { (Basi) }\end{array}$ & $\begin{array}{l}3509 \mathrm{Mpa} \\
\text { (Çeki) } \\
1731 \mathrm{Mpa} \\
\text { (Bas1) }\end{array}$ & $\begin{array}{l}559.816 \mathrm{Mpa} \\
\text { (Çeki) } \\
238.252 \mathrm{Mpa} \\
\text { (Bas1) }\end{array}$ & $\begin{array}{l}3153 \mathrm{Mpa} \\
\text { (Çeki) } \\
1.759 \mathrm{Mpa} \\
\text { (Basi) }\end{array}$ & $\begin{array}{c}82.27 \text { (çeki) } \\
0 \\
\text { (bası) }\end{array}$ \\
\hline
\end{tabular}

- $\quad$ Geometri șekilleri farklı, mesnetleri aynı toplam mekanik skala gerilim sonuçlarında ise, radyal ankastreli mesnetin düz mesnete göre $\mathrm{x}, \mathrm{z}$ eksenlerinde azaldığ 1 , y ekseninde ise arttı̆g1, bas1 oranlarının ise $\mathrm{x}$ ekseninde azaldı $\breve{1}, \mathrm{y}, \mathrm{z}$ eksenlerinde ise arttığı görülmüştür. Radyal çizgisel mesnetin düz mesnete göre, $\mathrm{z}$ ekseninde azaldığı, $\mathrm{x}, \mathrm{y}$ eksenlerinde arttığı, bası oranlarının ise radyal ankastreli mesnetin düz mesnete göre bası oranlarıyla aynı sonuçlarda tespit edildiği yani x ekseninde azaldı $\breve{g} 1, \mathrm{y}, \mathrm{z}$ eksenlerinde ise arttığ görülmüsstür. $\mathrm{Bu}$ sonuçlar, sandviç kompozit tabakaların konstrüktif açıdan iyi olduğunu göstermektedir. Farklı paket programları kullanarak (ABAQUS, Apex, Nastran gibi) benzer analizler yapılabilir ve birbirleriyle mukayese edilebilir (Taşkaya vd., 2018; Taşkaya, 2018). 
- Farklı modelli geometriler, farklı alan ölçüleri, oryantasyon açıları, malzeme türü, farklı çekirdek tabakası, element türü, mesh türü, yük miktarı, mesnetleme şekli değiştirilerek çözüm yaptırilip, malzemeler birbirleriyle kıyaslanabilinir. Uygulama alanındaki karmaşık geometriye sahip malzemeler, farklı sonlu elemanlar simülasyonlar programları sayesinde (ABAQUS, Apex, Nastran gibi) en basit hale dönüştürülerek prototipler oluşturulabilir ve sonuçları birbirleriyle karşılaştırılabilinir. $\mathrm{Bu}$ sayede basit geometrili modellerden birçok test analizleri (yap1, termal, titreşim, mekanik, statik, dinamik gibi) yapılabilir. Uygulama sanayisinde hafiflik ve rijitlik istenen (otomotiv, havacilık, uçak sanayi gibi) alanlarda kaplama malzemesi kullanılan bu modellemeler sandviç konstrüksiyon tekniği ile üretilip, bu gibi sonlu elemanlar simülasyon programları ile farklı tip analizler uygulanabilir (Taşkaya vd., 2018; Taşkaya, 2018).

\section{Teşekkür}

$\mathrm{Bu}$ çalışmanın sadeleştirilmiş özet bildirimi 46/05/2018 tarihinde Girne, K.K.T.C.'de düzenlenen " 3 rd International Conference on Computational Mathematics and Engineering Sciences (CMES'2018)-(Turkish Republic of Northern Cyprus)" kongresinde sözlü sunum olarak sunulmuş olup, kongre üyelerine teşekkür ederiz.

\section{Kaynaklar}

Atckinson, R., 1997. Innovative uses for sandwich constructions. Reinforced Plastics, 41(2), 30-33.

Bannister, M.K., Braemar, R. ve Crothers, I.P., 1999. The mechanical performance of 3D woven sandwich composites, Composite Structure, 47, 687-690.

Campbell, F.C., 2010. Structural Composite Materials: Novelty, Ohio, ASM International, 612p.

Froud, G.R., 1980. Your Sandwich order,Sir? Composites, 11(3), 133-138.

Ganapathi, M., Patel, B.P. ve Makhecha, D.P., 2004. Nonlinear dynamic analysis of thick composite/sandwich laminates using an accurate higher-order theory. Composites Part B: Engineering, 35, 345-355.

Gür, A.K., Taşkaya, S., Katı, N. ve Yıldız, T., 2017a. 3D Kafes çatı modelinin Ansys yöntemiyle mekanik gerilmelerinin incelenmesi, $2^{\text {nd }}$ International Conference on Material Science and Technology in Cappadocia (IMSTEC'17), Ekim 2017 Nevşehir, Türkiye, s. 11-15.

Gür, A.K., Taşkaya, S., Yıldız, T. ve Katı, N., 2017b. Metal Matrisli Kompozit Malzemelerde Sıcaklığın Etkisiyle Sürünme ve Elastik Özelliklerin Ansys Yöntemiyle İncelenmesi, $2^{\text {nd }}$ International Conference on Material Science and Technology in Cappadocia (IMSTEC'17), Ekim 2017 Nevşehir, Türkiye, s. 171-177.

Manning, JA., Crosky, AG. ve Bandyopadhay, S., 1993. Flexural and impact properties of sandwich panels used in surfboard construction. In: Proceedings of the International Conference on Advanced Composites, February 1993, Wollongong, Australia, pp.123-128.

Muc, A. ve Nogowczyk, R., 2005. Formy zniszczenia konstrukcji sandwiczowych $\mathrm{z}$ okładzinami wykonanymi z kompozytów. Composites, 5(4), 31-36.

Natarajan, S., Deogekar, P.S., Manickam, G. ve Belouettar, S., 2014. Hygrothermal effects on the free vibration and buckling of laminated composites with cutouts. Composite Structure, 108, 848-855.

Ochelski, S. ve Niezgoda, T., 2007. Kompozytowe konstrukcje pochłaniające energię uderzenia. Przegląd Mechaniczny, 1, 21-28.

Panigrahi, S.K. ve Pradhan, B., 2007. Delamination damage analyses of adhesively bonded lap shear joints in laminated frp composites. International Journal of Fracture Mechanics, 148, 373385.

Park, J.S., Kim, J.H. ve Moon, S.H., 2004. Vibration of thermally post-buckled composite plates embedded with shape memory alloy fibers. Composite Structure, 63, 179-188.

Polat, A., Kaya, Y. ve Özşahin, T.Ş., 2017. Fonksiyonel derecelendirilmiş tabakada sürekli temas probleminin sonlu elemanlar yöntemi ile analizi. 20. Ulusal Mekanik Kongresi, Eylül 2017, Bursa, Türkiye, s.332-341. 
Polat, A., Kaya, Y. ve Özşahin, T.Ş., 2018. Elastik yarı sonsuz düzlem üzerine oturan ağırlıklı tabakanın sonlu elemanlar yöntemi kullanılarak sürtünmesiz temas problemi analizi. Düzce Üniversitesi Bilim ve Teknoloji Dergisi, 6, 357-368.

Swanson, S.R. ve Kim, J.M., 2003. Design of sandwich structures under contact loading. Composite Structures, 59, 403-413.

Taşkaya, S., 2017. St 37 çeliğinin Ansys programında basınca bağlı olarak mekanik gerilmelerin incelenmesi. The Journal of International Manufacturing and Production Technologies, 1(1), 39-46.

Taşkaya, S., 2018. Investigation of mechanical and elastic stresses in Ansys program by finite elements method of 3D lattice roof model. Mugla Journal of Science and Technology, 4(1), 27-36.
Taşkaya, S., Zengin, B. ve Kaymaz, K., 2018. Investigation of force and moment effect of St 37 and St 70 roof lattice steels in Ansys program. Middle East Journal of Science, $4(1), 23-35$.

Tawfik, M., Ro, J.J. ve Mei, C., 2002. Thermal post-buckling and aeroelastic behaviour of shape memory alloy reinforced plates. Smart Materials and Structure, 11, 297-307.

Vangipuram, P. ve Ganesan, N., 2007. Buckling and vibration of rectangular composite viscoelastic sandwich plates under thermal loads. Composite Structure, 77, 419-429.

Zhang, F., Ramadan M., Baozhong, S. ve Bohong, G., 2013. Damage behaviors of foam sandwiched composite materials under quasi static three point bending. Applied Composite Materials, 20, 1231-1246. 